\title{
Trapped In His Skin
}

A budding young boy wanders the school, Footsteps patter to the beat of his heart. His classmates snicker and act too cruel, He wonders why life has fallen apart.

He is a night owl consoled by the dark. An angry lizard with scaly disease,

A birch tree with flaking layers of bark, A shape-shifting chameleon at unease.

Countless creams and oils provide no cure, His bright life's fabric tearing at its seams.

While he longs to be center stage, brave and sure, A teen superhero awaiting his dreams.

One day he says, "In the sun I feel better."

This epiphany brings light therapy.

He transforms from an active volcano,

To a sea of shining tranquility.

He smiles at me,

The trapped bird is free.

\section{Ami Saraiya}

Correspondence to Ami Saraiya MD, Department of Dermatology, Tufts Medical Center, 800 Washington St. Boston, MA 02111, USA; asaraiya@tuftsmedicalcenter.org

Competing interests None.

Provenance and peer review Not commissioned; internally peer reviewed.

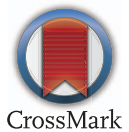

To cite Saraiya A. Med Humanit 2015;41:e10.

Med Humanit 2015;41:e10. doi:10.1136/medhum-2014-010651 